\title{
Distribution of 18s rDNA variants of Diderma hemisphaericum (Myxomycota) specimens obtained from moist chambers of materials collected in the Philippines and Vietnam
}

\author{
King Joshua Almadrones-Reyes ${ }^{1}$, John Lorenzo M. Bernardo ${ }^{1}$, John Carlo Redeña-Santos ${ }^{2}$, \\ Nikki Heherson A. Dagamac ${ }^{3 *}$
}

\begin{abstract}
Since there are only limited biogeographic studies of myxomycetes in Southeast Asia, this study was conducted to assess the molecular diversity of Diderma hemisphaericum, a cosmopolitan myxomycetes species that abundantly occurs in most moist chamber collections in tropical Southeast Asia. Specimens that contain D. hemisphaericum were gathered from various parts of the Philippines: (i) Los Banos, (ii) Calauan, (iii) Basud, (iv) Isarog and (v) Malilipot; and Vietnam: (i) Thai Nguyen (ii) Ha Noi and (iii) Da Nang. Using modern molecular techniques, the common barcode nuclear marker $18 \mathrm{~S}$ rDNA for myxomycetes was targeted for the 50 specimen used in this study. A total of 27 ribotypes (11 from the Philippines and 16 from Vietnam) were obtained. The Mantel test showed that genetic differentiation among ribotypes is not correlated with geographic distances. The FST index (0.083) indicates high genetic intermixing between the Philippines and Vietnam. Hence, it seems that the variation across regional scale gene pool is not directly influenced by geographic isolation but rather by environmental selection.
\end{abstract}

Keywords: AMOVA, biogeography, long distance dispersal, ribotype, tropics, slime molds

\section{Introduction}

Our knowledge of how certain biological organism is distributed worldwide is considered to be the major tenet of any biogeographical understanding (Pimm et al., 2014). These instigated many debates about patterns of global distribution among many macroorganisms, including pine trees (CarrilloGavilán et al., 2015), lianas (DeWalt et al., 2015), and spiders (Boyer et al., 2016), but only limited models have been proposed for microorganisms. Nonetheless, understanding the most appropriate biogeographical hypothesis of global distribution is important particularly in the light of the undergoing estimation of the Earth's total biodiversity (McGill

\footnotetext{
${ }^{1}$ Advanced Education Program, Thai Nguyen University of Agriculture and Forestry, Quyết Thắng, Thái Nguyên, Vietnam

${ }^{2}$ Institute of Biological Sciences, University of the Philippines Los Baños, College, Laguna 4031, Philippines

${ }^{3}$ Institute of Botany and Landscape Ecology, University of Greifswald, Soldmannstr. 15, D-17487, Greifswald, Germany

*Corresponding email: nhadagamac@gmail.com

Date Submitted: 30 January 2019

Date Accepted: 11 August 2019
}

et al., 2015). For example in the case of myxomycetes, we can assume that if all myxomycetes are widely distributed, then their global diversity is low. On the other hand, if myxomycetes are restricted in terms of their geographic distribution and their patterns are not by merely caused by their expected habitat requirements, then their global diversity should be high (Mitchell \& Meisterfeld, 2005). So far, two opposing models for protist biogeography are still in debate for the biogeographic patterns of myxomycetes (Schnittler et al., 2017a).

The first hypothesis is known as the Everything is Everywhere (EiE) model. According to this model, due to their relatively small spore size, like other microorganisms, myxomycetes (or true plasmodial slime molds) are expected to follow the Baas-Becking model of microbial ubiquity in nature (Finlay, 2002). For example, the Taimyr Peninsula, located in the Far North of Russia, has an extremely low temperature but Cribaria violacea, a type of myxomycetes that can be found usually in tropical regions, has been found in this region (Novozhilov et al., 1999). Another example is the recent new records of Redeña-Santos et al. (2017) and Bernardo et al. (2018). They found that what seems to be an exclusively temperate myxomycete is reported for the first time in the subtropical climate of Northern Vietnam and fragmented forest in tropical Philippines, respectively. This model is further 
supported by other studies that showcased rapid rates of dispersal for some metacommunities of protists (see studies of Berdjeb et al., 2018). Most of these studies showed that protists are capable of long distance dispersals due to several abiotic factors such as wind (van der Gast, 2015), volcanic eruption (Bass \& Boegnik, 2011) or the intervention of biological vectors of dispersal such as birds (Wilkinson et al., 2012), and even human movements (Perrigo et al., 2012). However, an opposing second hypothesis about these general biogeographical patterns for protist also has been proposed. A popular model that refutes the former model is the model first proposed by Foissner (1999) which is known as Moderate endemicity (ME). According to this model, even if there are myxomycetes species that can be cosmopolitan or globally distributed, portion of the ca. 1000 morphospecies (Lado, 2018) have their own geographically restricted distribution (Foisner, 2006). For example, geographical barriers such as mountain ranges (Boenigk et al., 2018), oceans (Dagamac et al., 2017a) may serve as a hindrance for myxomycetes to disperse and be distributed like in the case of plants (Ixora, Mouly \& Pisivin, 2007; Nepenthes, van der Ent et al., 2015; Cinnamomum, Sriramavaratharajan et al., 2016) or animals (Mimus parvulus, Gotanda et al., 2015; Drosophila, Craddock et al., 2016; Tropidurus tropiduridae, de Carvalho et al., 2007), that are argued to have a native restriction at a local scale (Cotterill et al., 2008). In the arguments published by Foissner (2008), the ME model contradicts EiE by proposing the following parameters: (i) migration rates are lower in $90 \%$ of the known species therefore yielding at the same time low abundance rate, (ii) the ability of a species to get extinct will be moderate, (iii) the ratio of the global species pool that are found in local scale setting is again moderate and (iv) at least $30 \%$ of the morphospecies are considered to be restricted or endemic. In cases of recent myxomycete studies, it seems that this model is more strongly favored. For instance, there is the case of the genus Ceratiomyxa in which two species namely Ceratiomyxa morchella and Ceratiomyxa sphaerosperma (Rojas et al., 2008) are found only in the tropical region of Central America. Moreover, the patchy distributional range of the unfathomable myxomycete species Barbeyella minutissima (Schnittler et al., 2000) points out the exclusivity of this myxomycete species to temperate Picea and/or Abies type of forests. However, these observations are just only recently supported by Dagamac et al. (2017b) using sophisticated ecological community models that compared the diversities and distribution of tropical myxomycetes. In that study, a clear bifurcation between the Neotropical and Asian Palaeotropical forest myxomycete communities was illustrated due to the number of regional endemic species recorded for the two forests.
However most of this studies concentrated at the morphospecies level. Recent investigations that utilized partial 18S rDNA of some cosmopolitan myxomycete populations have been tested to address which of the two proposed hypothesis of protist biogeography myxomycetes follow. As such, the population genetic studies using the myxomycete models Badhamia melanospora (Aguilar et al., 2014) and Hemitrichia serpula (Dagamac et al., 2017b) seems to both agree that at a wider global scale, geographical barriers limit the distribution of myxomycete species and eventually leads to a number of cryptic biospecies. However, at a finer regional scale like in the case of Southeast Asian populations, distributions of partial 18S rDNA variants (ribotypes) are still unexplored. Hence, this study was conducted to compare the population of Diderma hemisphaericum, another clear cut and widely distributed myxomycete species across the Southeast Asian tropics.

Diderma hemisphaericum (Bull.) Hornemann is a "chocolate crinkle" looking myxomycetes species that was first described in Flora Danica. This species is reported in the temperate countries of Europe according to the Global Biodiversity Information Facility (GBIF) web portal and studies of Chen et al. (2013). However, recent studies in Palaeotropical forests in Southeast Asian countries that employed moist chamber cultures (see studies of Redeña-Santos et al., 2017; Rosing et al., 2011; Ko Ko et al., 2010), shows that $D$. hemisphaericum can just not also thrive and effortlessly found in a tropical and subtropical climate but also expand under changing climate scenarios (Almadrones-Reyes \& Dagamac, 2018). This now makes this myxomycete species a good candidate to check the possibility of regional range 18sRDNA gene flow between Philippines and Vietnam.

\section{Materials and Methods}

\section{DNA extraction, amplification and sequencing}

A total of 50 samples of Diderma hemisphaericum were obtained from the herbarium collection of the last author. From these collections, two set of Southeast Asian populations namely from the (i) Philippines and (ii) Vietnam were selected for this study. Following the protocol of Dagamac et al. (2017a), approximately 10 mature fructifications coming from the herbarium collections were manually transferred into a $2 \mathrm{ml}$ sterile safe-lock eppendorf tubes with glass beads and coarse sand. To maintain the aseptic condition during the transfer of fruiting bodies, the working space was initially washed with $70 \% \mathrm{EtOH}$. To further avoid cross contamination between the samples, the forceps were chemically sterilized by washing it concurrently with $1 \mathrm{M} \mathrm{HCl}$, detergent solution and $70 \% \mathrm{EtOH}$. After transferring, the samples were then immediately 
mechanically crushed using a microtube homogenizer (Bead Blaster $^{\mathrm{TM}}$ 24, Benchmark Scientific, USA). Next, the DNA extraction using Mag-Bind Plant DNA Kit (Omega Bio- tek, Georgia, USA) was done following the manufacturer's protocol. After, the processing of the magnetic bead set-up, the samples was then extracted using the robot model KingFisher ${ }^{\mathrm{TM}}$ Flex (ThermoScientific, Germany). Then, the amplicons from the extracted DNA samples has been produced following the modified PCR condition from Shchepin et al. 2017 and by making the following combination for a master mix PCR solution: $5.64 \mu \mathrm{L}$ of $\mathrm{H} 20,0.50 \mu \mathrm{L}$ of colored buffer ( $5 \times$ MgoBuffer), $1 \mu \mathrm{L}$ of $\mathrm{MgCl}_{2}$ (Bioline, $50 \mathrm{mM}$ ), $0.20 \mathrm{uL}$ of dNTPs, 0.25 of forward and reverse primer ( $\mathrm{S} 1$ and Su19Rsp, see Schnittler et al. 2017b), $0.16 \mu \mathrm{L}$ of Mango- Taq DNA Polymerase (5U/ $\mu \mathrm{L})$ and lastly, $2 \mu \mathrm{L}$ of diluted DNA (10ng/ $\mu \mathrm{L})$ was added totalling in $10 \mu \mathrm{L}$ in volume. Next, to check if the amplification process was successful, visualization of the DNA was performed by using $1.8 \%$ agarose gel electrophoresis for 45 minutes at $100 \mathrm{~V}$. To view the generated bands on the gel product, UV trans- illuminator (BST- 20G- 8R) was used. All successfully amplified DNA samples that have produced clear bands were separated for the purification step using enzymes (Exonuclease and Alkalic Phosphatase - EAP). After subjecting the purified amplicons $\left(37^{\circ}\right.$ Celsius, for 1 hour and $85^{\circ}$ Celsius for 15 minutes), the concentration was measured using Nanodrop at an OD of $260 \mathrm{~nm}$ for double stranded DNA (Nanodrop ${ }^{\text {TM }}$ Lite Spektralphotometer Thermo Scientific ${ }^{\mathrm{TM}}$ ) and was then adjusted to get the final concentration of $10 \mathrm{ng} / \mu \mathrm{L}$.

Now to perform the cycle sequencing process, the following mastermix combination was prepared: $1.5 \mu \mathrm{L}$ sequencing buffer, $4.69 \mathrm{ddH}_{2} \mathrm{O}, 4.00 \mu \mathrm{L}$ big Dye, $4.00 \mu \mathrm{L}$ Half big dye and $0.625 \mu \mathrm{L}$ of the S1 forward and reverse primer. Then, the products of the PCR process were cleaned with serial ethanol washing $(30 \mu \mathrm{l}$ of $96 \% \mathrm{EtOH}$ and $100 \mu \mathrm{l}$ of $70 \%$ EtOH). After overnight incubation, the samples placed inside a 96 well plate were sent to the Zoology department of the University of Greifswald for sequencing purposes using the ABI3730 sequencer.

\section{Quality filtering and sequence alignment.}

The qualities of the DNA sequences were initially validated using the sequence reader software Chromas and were cross checked using the Nucleotide BLAST (Basic Local Alignment Search Tool) Database. Sequences that gave an Evalue of 0.00 and had a high percentage similarity to Diderma sequences found in the database were then used to the subsequent analysis. After quality filtering of the generated sequences, an automatic alignment algorithm using the online version of MAFFT (multiple alignment using fast Fourier transform) software were employed using the following parameters set in Dagamac et al. (2017a): E- INS- i setting with a 2.5 gap penalty. The new alignment file of the partial $18 \mathrm{~S}$ rDNA was comprised of ca. 539 positions and was then manually edited by checking the sequence quality using BioEdit v7.0.5. Initially the both ends having the first and last ca. 20 base pairs that provided low quality sequences were shortened. The final alignment were then trimmed down for only 505 base sites which were used for further data analyses

\section{Data analyses}

An analysis based on the most statistically parsimonious gene network for ribotypes having $95 \%$ coherence in accordance to the set of possible outcomes based on coalescent theory (Hudson, 1989) was constructed for this study. The ribotype networks separated by mutational steps were created using the software TCS v.1.21 (Clement et al., 2000) which is based on the calculation of the probability that pairs of ribotypes are similar for all other combinations of ribotypes and then connects only the most similar ribotypes together into a network where their combined probability is $>95 \%$. Therefore, the resulting network will remove divergent ribotypes whose true genealogy may be concealed by homoplastic characters (Templeton \& Sing, 1993).

To estimate the genetic diversity of the $D$. hemisphaericum population in (i) the Philippines and (ii) Vietnam, a RAC (ribotype accumation curve) were constructed using the values generated from the default settings in EstimateS v.9 (200 randomizations, Colwell, 2013). Next, the correlation between the genetic and geographic distances was also calculated by constructing two independent matrices: (i) matrix consisting of the genetic distance from the $505 \mathrm{bp}$ multiple sequence alignment of samples was implemented in MEGA v. 7.0 with the following option summary: (variation estimation method = Bootstrap, $\operatorname{model} / \operatorname{method}=$ Maximum Composite Likelihood, substitutions to include $=$ Transitions + Transversions, rates among sites = Gamma distributed) and (ii) the matrix which includes the geographical distances between the collection sites of any two samples being compared as calculated using an Excel template with the Vincenty formula (Dalgleish, 2018). The two matrices were then subjected to a Mantel test with 999 iterations in the ExtraStats function in PopTools v3.2.5 (Hood, 2010). Afterwards, to detect the differentiation of ribotypes between the Philippine and Vietnam populations, an AMOVA (analysis of molecular variance) and genetic differentiation calculated as Chi -square statistics was done using Arlequin 3.5.2.2 (Excoffier \& Lischer, 2010) with a significance based on 10000 permutations. To analyze the polymorphic sites that yielded the diversity of the ribotypes and mean number of nucleotide differences were 
Table 1. List of samples of Diderma hemisphaericum with their corresponding location, collector, ribotype number, and coordinate.

\begin{tabular}{|c|c|c|c|c|c|c|c|}
\hline $\begin{array}{c}\text { Sample } \\
\text { No }\end{array}$ & Col No. & Collector & $\begin{array}{c}\text { Region / } \\
\text { City }\end{array}$ & Country & Ribotype & Latitude N & Longitude E \\
\hline 1 & A80 & JCS & Thai Nguyen & $\overline{\text { Vietnam }}$ & $\mathrm{r} 1$ & $21^{\circ} 35^{\prime} 39^{\prime \prime}$ & $105^{\circ} 50^{\prime} 53^{\prime \prime}$ \\
\hline 2 & B123 & JCS & Thai Nguyen & Vietnam & r2 & $21^{\circ} 35^{\prime} 39^{\prime \prime}$ & $105^{\circ} 50^{\prime} 53^{\prime \prime}$ \\
\hline 3 & B42 & JCS & Thai Nguyen & Vietnam & r2 & $21^{\circ} 35^{\prime} 39^{\prime \prime}$ & $105^{\circ} 50^{\prime} 53^{\prime \prime}$ \\
\hline 4 & B04 & JCS & Thai Nguyen & Vietnam & $\mathrm{r} 2$ & $21^{\circ} 35^{\prime} 39^{\prime \prime}$ & $105^{\circ} 50^{\prime} 53^{\prime \prime}$ \\
\hline 5 & C144 & JCS & Thai Nguyen & Vietnam & $\mathrm{r} 2$ & $21^{\circ} 35^{\prime} 39^{\prime \prime}$ & $105^{\circ} 50^{\prime} 53^{\prime \prime}$ \\
\hline 6 & $\mathrm{C} 143$ & JCS & Thai Nguyen & Vietnam & r2 & $21^{\circ} 35^{\prime} 39^{\prime \prime}$ & $105^{\circ} 50^{\prime} 53^{\prime \prime}$ \\
\hline 7 & TH38 & NHAD & Thai Nguyen & Vietnam & $\mathrm{r} 2$ & $21^{\circ} 34^{\prime} 00^{\prime \prime}$ & $105^{\circ} 41^{\prime} 00^{\prime \prime}$ \\
\hline 8 & $\mathrm{C} 84$ & JCS & Thai Nguyen & Vietnam & r3 & $21^{\circ} 35^{\prime} 39^{\prime \prime}$ & $105^{\circ} 50^{\prime} 53^{\prime \prime}$ \\
\hline 9 & $\mathrm{C} 50$ & JCS & Thai Nguyen & Vietnam & r3 & $21^{\circ} 35^{\prime} 39^{\prime \prime}$ & $105^{\circ} 50^{\prime} 53^{\prime \prime}$ \\
\hline 10 & TH32 & NHAD & Thai Nguyen & Vietnam & r4 & $21^{\circ} 34^{\prime} 00^{\prime \prime}$ & $105^{\circ} 41^{\prime} 00^{\prime \prime}$ \\
\hline 11 & TH42 & NHAD & Thai Nguyen & Vietnam & r5 & $21^{\circ} 34^{\prime} 00^{\prime \prime}$ & $105^{\circ} 41^{\prime} 00^{\prime \prime}$ \\
\hline 12 & $\mathrm{C} 21$ & JCS & Thai Nguyen & Vietnam & r6 & $21^{\circ} 35^{\prime} 39^{\prime \prime}$ & $105^{\circ} 50^{\prime} 53^{\prime \prime}$ \\
\hline 13 & TH12 & NHAD & Thai Nguyen & Vietnam & r7 & $21^{\circ} 34^{\prime} 00^{\prime \prime}$ & $105^{\circ} 41^{\prime} 00^{\prime \prime}$ \\
\hline 14 & A23 & JCS & Thai Nguyen & Vietnam & r8 & $21^{\circ} 35^{\prime} 39^{\prime \prime}$ & $105^{\circ} 50^{\prime} 53^{\prime \prime}$ \\
\hline 15 & B22 & JCS & Thai Nguyen & Vietnam & r9 & $21^{\circ} 35^{\prime} 39^{\prime \prime}$ & $105^{\circ} 50^{\prime} 53^{\prime \prime}$ \\
\hline 16 & TH41 & NHAD & Thai Nguyen & Vietnam & $\mathrm{r} 10$ & $21^{\circ} 34^{\prime} 00^{\prime \prime}$ & $105^{\circ} 41^{\prime} 00^{\prime \prime}$ \\
\hline 17 & TH31 & NHAD & Thai Nguyen & Vietnam & $\mathrm{r} 10$ & $21^{\circ} 34^{\prime} 00^{\prime \prime}$ & $105^{\circ} 41^{\prime} 00^{\prime \prime}$ \\
\hline 18 & TH35 & NHAD & Thai Nguyen & Vietnam & r11 & $21^{\circ} 34^{\prime} 00^{\prime \prime}$ & $105^{\circ} 41^{\prime} 00^{\prime \prime}$ \\
\hline 19 & CA82 & JLB & Calauan & Philippines & $\mathrm{r} 12$ & $14^{\circ} 05^{\prime} 00^{\prime \prime}$ & $121^{\circ} 15^{\prime} 00^{\prime \prime}$ \\
\hline 20 & LB81 & JLB & Los Banos & Philippines & r12 & $14^{\circ} 10^{\prime} 12^{\prime \prime}$ & $121^{\circ} 14^{\prime} 39^{\prime \prime}$ \\
\hline 21 & No Label & JLB & Los Banos & Philippines & $\mathrm{r} 12$ & $14^{\circ} 10^{\prime} 12^{\prime \prime}$ & $121^{\circ} 14^{\prime} 39^{\prime \prime}$ \\
\hline 22 & LB42 & JLB & Los Banos & Philippines & r12 & $14^{\circ} 10^{\prime} 12^{\prime \prime}$ & $121^{\circ} 14^{\prime} 39^{\prime \prime}$ \\
\hline 23 & BAGL23 & NHAD & Basud & Philippines & $\mathrm{r} 12$ & $14^{\circ} 3^{\prime} 39^{\prime \prime}$ & $122^{\circ} 57^{\prime} 50^{\prime \prime}$ \\
\hline 24 & CA102 & JLB & Calauan & Philippines & $\mathrm{r} 12$ & $14^{\circ} 05^{\prime} 00^{\prime \prime}$ & $121^{\circ} 15^{\prime} 00^{\prime \prime}$ \\
\hline 25 & LB50 & JLB & Los Banos & Philippines & r13 & $14^{\circ} 10^{\prime} 12^{\prime \prime}$ & $121^{\circ} 14^{\prime} 39^{\prime \prime}$ \\
\hline 26 & MAAL25 & NHAD & Malilipot & Philippines & r14 & $13^{\circ} 18^{\prime} 14^{\prime \prime}$ & $123^{\circ} 44^{\prime} 25^{\prime \prime}$ \\
\hline 27 & LB45 & JLB & Los Banos & Philippines & r15 & $14^{\circ} 10^{\prime} 12^{\prime \prime}$ & $121^{\circ} 14^{\prime} 39^{\prime \prime}$ \\
\hline 28 & LB101 & JLB & Los Banos & Philippines & r16 & $14^{\circ} 10^{\prime} 12^{\prime \prime}$ & $121^{\circ} 14^{\prime} 39^{\prime \prime}$ \\
\hline 29 & A22 & JCS & Thai Nguyen & Vietnam & r17 & $21^{\circ} 35^{\prime} 39^{\prime \prime}$ & $105^{\circ} 50^{\prime} 53^{\prime \prime}$ \\
\hline 30 & A65 & JCS & Thai Nguyen & Vietnam & r18 & $21^{\circ} 35^{\prime} 39^{\prime \prime}$ & $105^{\circ} 50^{\prime} 53^{\prime \prime}$ \\
\hline 31 & TH01 & NHAD & Thai Nguyen & Vietnam & r18 & $21^{\circ} 34^{\prime} 00^{\prime \prime}$ & $105^{\circ} 41^{\prime} 00^{\prime \prime}$ \\
\hline 32 & TH53 & NHAD & Thai Nguyen & Vietnam & r18 & $21^{\circ} 34^{\prime} 00^{\prime \prime}$ & $105^{\circ} 41^{\prime} 00^{\prime \prime}$ \\
\hline 33 & $\mathrm{C} 26$ & JCS & Thai Nguyen & Vietnam & r18 & $21^{\circ} 35^{\prime} 39^{\prime \prime}$ & $105^{\circ} 50^{\prime} 53^{\prime \prime}$ \\
\hline 34 & HA38 & NHAD & Hanoi & Vietnam & r18 & $21^{\circ} 55^{\prime} 00^{\prime \prime}$ & $105^{\circ} 18^{\prime} 00^{\prime \prime}$ \\
\hline 35 & TH51 & NHAD & Thai Nguyen & Vietnam & r18 & $21^{\circ} 34^{\prime} 00^{\prime \prime}$ & $105^{\circ} 41^{\prime} 00^{\prime \prime}$ \\
\hline 36 & TH10 & NHAD & Thai Nguyen & Vietnam & r18 & $21^{\circ} 34^{\prime} 00^{\prime \prime}$ & $105^{\circ} 41^{\prime} 00^{\prime \prime}$ \\
\hline 37 & CA68 & JLB & Calauan & Philippines & r19 & $14^{\circ} 05^{\prime} 00^{\prime \prime}$ & $121^{\circ} 15^{\prime} 0^{\prime \prime}$ \\
\hline 38 & ISAL29 & NHAD & Isarog & Philippines & r19 & $13^{\circ} 39^{\prime} 05^{\prime \prime}$ & $123^{\circ} 25^{\prime} 38^{\prime \prime}$ \\
\hline 39 & LB70 & JLB & Los Banos & Philippines & $\mathrm{r} 20$ & $14^{\circ} 10^{\prime} 12^{\prime \prime}$ & $121^{\circ} 14^{\prime} 39^{\prime \prime}$ \\
\hline 40 & LB24 & JLB & Los Banos & Philippines & r21 & $14^{\circ} 10^{\prime} 12^{\prime \prime}$ & $121^{\circ} 14^{\prime} 39^{\prime \prime}$ \\
\hline 41 & CA83 & JLB & Calauan & Philippines & $\mathrm{r} 22$ & $14^{\circ} 4^{\prime} 60^{\prime \prime}$ & $121^{\circ} 15^{\prime} 00^{\prime \prime}$ \\
\hline 42 & ISAL21 & NHAD & Isarog & Philippines & r23 & $13^{\circ} 39^{\prime} 05^{\prime \prime}$ & $123^{\circ} 25^{\prime} 38^{\prime \prime}$ \\
\hline 43 & DN15 & NHAD & Danang & Vietnam & r24 & $15^{\circ} 55^{\prime} 00^{\prime \prime}$ & $107^{\circ} 18^{\prime} 00^{\prime \prime}$ \\
\hline 44 & DN24 & NHAD & Danang & Vietnam & r24 & $15^{\circ} 55^{\prime} 00^{\prime \prime}$ & $107^{\circ} 18^{\prime} 00^{\prime \prime}$ \\
\hline 45 & ISAL02 & NHAD & Isarog & Philippines & r25 & $13^{\circ} 39^{\prime} 05^{\prime \prime}$ & $123^{\circ} 25^{\prime} 38^{\prime \prime}$ \\
\hline 46 & $\mathrm{C} 23$ & JCS & Thai Nguyen & Vietnam & r26 & $21^{\circ} 35^{\prime} 39^{\prime \prime}$ & $105^{\circ} 50^{\prime} 53^{\prime \prime}$ \\
\hline 47 & HA41 & NHAD & Hanoi & Vietnam & r27 & $21^{\circ} 55^{\prime} 00^{\prime \prime}$ & $105^{\circ} 18^{\prime} 00^{\prime \prime}$ \\
\hline 48 & DN84 & NHAD & Danang & Vietnam & no amplicons & & \\
\hline 49 & CA61 & JLB & Calauan & Philippines & no amplicons & & \\
\hline 50 & CA81 & JLB & Calauan & Philippines & no amplicons & & \\
\hline
\end{tabular}


implemented using the software DnaSP v. 5.10 (Librado \& Rojas, 2009).

\section{Results}

A total of 47 out of 50 samples of Diderma hemisphaericum yielded successful amplicons (94\%). The distribution of these 47 amplicons showed 30 came from Vietnam and 17 came from the Philippines. From these 47 amplicons, 27 different ribotypes were accounted (See Table 1). These ribotypes were distributed wherein 11 ribotypes came from the Philippines population and 16 ribotypes came from Vietnam population yielding a ribotype density (Hd) of 0.88 and 0.91 respectively (Table 2 ). The ribotype accumulation curve (RAC) constructed for the two populations revealed $22.4 \%$ of the Philippines and $56.9 \%$ of Vietnam were surveyed as shown in Fig. 3. The Cole rarefaction curve (Fig 1) showed that both regions have at least the same genetic diversity in terms of the collected samples.

Table 2. Summary of the polymorphic site analysis comparing the two countries generated by the DNAsp v.5. 1: (i) Philippines and (ii) Vietnam.

\section{PHILIPPINES VIETNAM}

\begin{tabular}{lcc}
\hline Number of sequences & 17 & 30 \\
Number of segregating sites & 98 & 98 \\
Number of ribotypes & 11 & 16 \\
$\begin{array}{l}\text { Ribotype diversity (Hd) } \\
\begin{array}{l}\text { Average number of } \\
\text { differences }\end{array}\end{array}$ & 0.88 & 0.91 \\
Nucleotide diversity & 33.07 & 28.05 \\
\hline
\end{tabular}

The genetic differentiation of the 27 ribotypes showed a strong significant difference $(\mathrm{p}=0.007, \alpha=0.01)$. However, to check if this genetic differentiation can be explained by their location, the correlation analysis between genetic and geographic distances was performed using the Mantel test for the 47 sequences. The result showed that the $r$ value $(0.1260)$ was within the $95 \%$ confidence interval (- 0.0851 to 0.1820 ). This is further corroborated when the percentage component of the analysis of molecular variance (AMOVA, Table 3) showed higher proportion "within the population" (91.678) than "between the population" (8.322). Moreover, the FST index computed in Arlequin yielded a value of 0.083. A clear intermixing of the ribotypes between the collections from the
Philippines and Vietnam was also concurred when a gene network was constructed (Fig. 2).

Table 3. AMOVA (Analaysis of molecular variance) displays the computed FST index (0.083), with (0) indicating genetic material sharing and (1) as no sharing.

\begin{tabular}{lccc}
\hline $\begin{array}{l}\text { Source of } \\
\text { Variation }\end{array}$ & $\begin{array}{l}\text { Sum of } \\
\text { squares }\end{array}$ & $\begin{array}{l}\text { Variance } \\
\text { component }\end{array}$ & $\begin{array}{c}\text { Percentage } \\
\text { component }\end{array}$ \\
\hline $\begin{array}{l}\text { Among } \\
\text { populations }\end{array}$ & 44.303 & 1.354 & 8.322 \\
$\begin{array}{l}\text { Within } \\
\text { populations }\end{array}$ & 671.229 & 14.916 & 91.678 \\
TOTAL & 715.532 & 16.270 & \\
FST index & $\mathbf{0 . 0 8 3}$ & & \\
\hline
\end{tabular}

\section{Discussion}

During the past few years, there have been numerous studies of myxomycete biodiversity in Southeast Asia, especially in Vietnam (131 records, see studies of RedeñaSantos et al., 2018; Novozhilov et al., 2018; Tran et al., 2014) and the Philippines (158 records, see studies of Bernardo et al., 2018; Macabago et al., 2017; Dagamac \& dela Cruz, 2015). Together with Thailand (145 records, Dagamac et al. 2017b; Ko Ko et al., 2010; Tran et al., 2008), these two countries are considered to be the three most myxomycete-rich countries for the region. However, much of the efforts conducted for the myxomycetes studies in the region are concentrated on morphological-based ecological surveys. Comparing Vietnam and the Philippines, the latter country has undergone during the last four decades (see studies of Macabago et al., 2012; Dagamac et al., 2012; Macabago et al., 2010; Dogma, 1975; Uyenco 1973) much more of these aforementioned surveys than the former which has a growing myxomycete studies during only the last five years. This status quo brought the idea to conduct this pilot study for the region which explores the diversity of a certain myxomycetes species at a genetic level to address if physical geographic barriers can affect the genetic diversity across regional populations of Diderma hemisphaericum.

\section{Ribotype diversity between Vietnam and Philippines}

In terms of genetic diversity, a total of 27 ribotypes of Diderma hemisphaericum have been identified. However, as shown in the figures $1 \mathrm{a}$ and $1 \mathrm{~b}$, only $22.4 \%$ of total genetic diversity was explored from the Philippines and $56.9 \%$ in Vietnam. This can be explained by the limited $D$. 


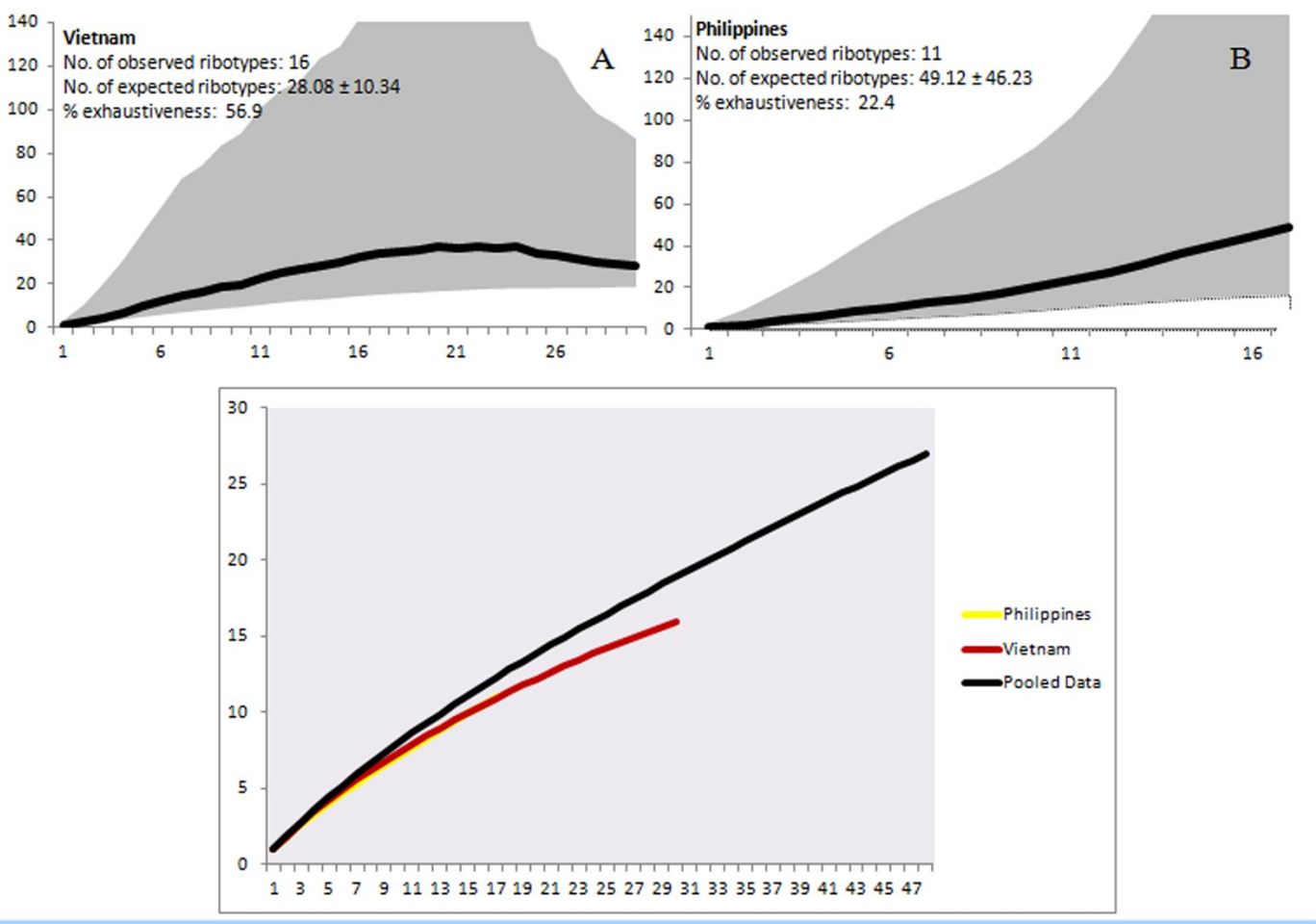

Figure 1. Ribotype accumulation curve based on the Chao 1 estimates in (A) Vietnam and (B) Philippines. The dark blackline shows the Chao 1 mean and the grey highlight indicates the $5 \%$ and 95\% limits. (C) A smooth ribotype accumulation curve based on Coleman rarefaction

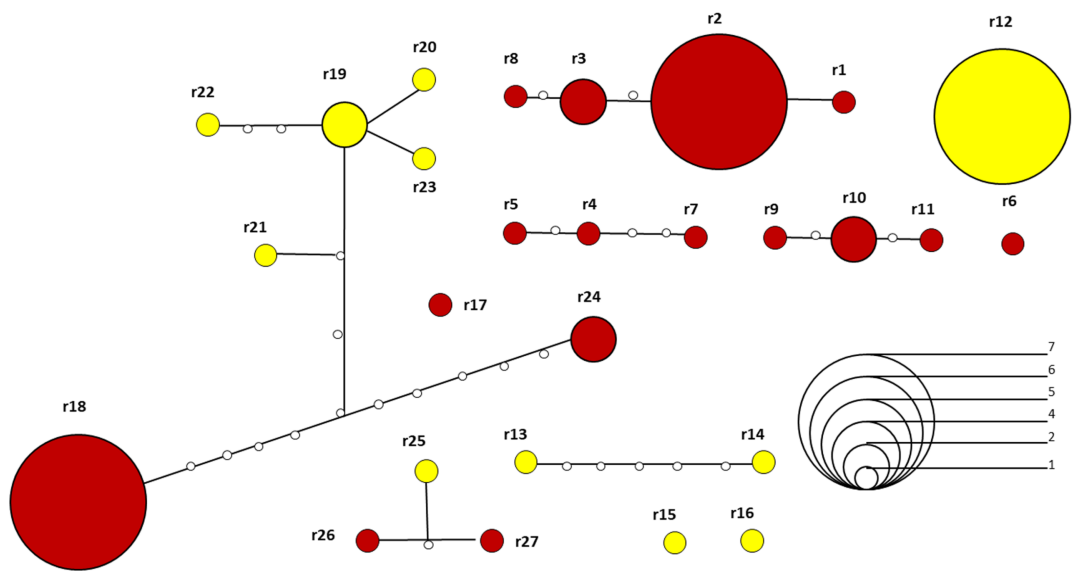

Figure 2. The constructed ribotype network using TCS. The circle size indicates the number of sequences represented by the ribotypes. The connecting line segments indicate mutational steps between alleles and the small circle in between represent the hypothetical transitional ribotypes. Colors of the circles indicate their collection origin: red (Vietnam) and yellow (Philippines). 
hemisphaericum samples only coming from the available herbarium collections at the Institute of Botany and Landscape Ecology, Greifswald, Germany. In spite of this, the rarefaction point of the ribotype accumulation curve (Fig. 1c) showed that both the Philippines and Vietnam have almost similar ribotype diversity. In a related study of Feng \& Schnittler (2017), a ribotype accumulation curve was also constructed for the diversity estimation of myxomycetes of several fruiting bodies collected in a deciduous forest in northeastern Germany. The results of their survey did not also reach an asymptotic curve similar with what this study obtained. With the exception of the species of Hemitrichia calyculata found on their study, this is perhaps due to the possibility of several ribotypes for a single morphological species. Thus, Feng \& Schnittler, (2017) suggested that molecular assessments of diversity should be coupled with extensive morphological approaches to create at least the exact diversity estimation. Nonetheless, to achieve a comparable genetic diversity between the two regions, more samples of $D$. hemisphaericum coming from other herbarium collections and extensive field surveys for both countries is recommended.

\section{Genetic differentiation of regional population opposes global biogeographical pattern}

Genetic differentiation is expected when comparing populations coming from different countries within the region. However, in the case of this study, genetic differentiation is more prominent "within the population" than "between the population". This is supported by the results of the AMOVA and chi-squared test that showed on one hand that the genetic variation between (interspecific) the samples of Philippines and Vietnam has no significant difference and on the other hand the genetic variations found among specimens within a specific region (intraspecific) are statistically significant. This simply means that there is an active gene flow that might be happening inside the regional gene pool. The FST index showed a low value of 0.083 , indicating high genetic intermixing between the Philippines and Vietnam. This can also be explained by the intermixing of 2 specimens having $\mathrm{r} 24$ variants and 7 specimens having r18 variants from $\mathrm{Da}$ Nang and Northern Vietnam (Hanoi, and Thai Nguyen), respectively with the r19, r23, r20, r22, and r21 from the Philippines from the gene network (Fig 2). Since microorganisms are well known to travel long distances due to their relatively small sizes, long distance dispersal of microorganisms for protists and fungi (see studies of Bonito et al., 2010; Moncalvo \& Buchanan, 2008) is not that surprising. This could be the exact same case for, Diderma hemisphaericum, which was already theoretically hypothesized to actively disperse across long distances (Kamono et al., 2009).
Hence, the regional geographic barriers between Philippines and Vietnam could not be that strong enough to hinder the regional gene flow. Interestingly, this is corroborated by the Mantel test that showed no correlation ( $\mathrm{r}$ value $=0.1260$ ) between genetic distances and geographical distances between the populations of the Philippines and Vietnam. This finding now seems to support the EiE (Everything is everywhere) model of biogeographic distribution for myxomycetes that states that microorganisms can have almost unlimited long distance dispersal but with the condition that the environment will be suitable for them to live (DeWit \& Bouvier, 2006). A similar case study of a miteassociated fungus, Knoxdaviesia proteae, revealed that large distances and geographical barriers do not isolate its population in the Core Cape Subregion of South Africa due to some vectors of dispersals like for example birds (Aylward et al., 2015). Interestingly, this predicament now seems to contradict several recent studies of myxomycetes biogeographical investigations. Like for an instance, a study of Dagamac et al., 2017a about 18sRDNA variants of Hemitrichia serpula, suggested a limited gene flow between continents caused by geographical barriers. Another case study about myxomycete biogeography is the study of Badhamia melanospora 18sRDNA variants that revealed an isolation of populations between the continents of North America, South America and the Old World (Aguilar et al., 2014). But to address this, both studies look at a global biogeographic scale which could most likely still support the moderate endemicity model. Perhaps, patterns for Diderma hemisphaericum would be clearer if a global scale population genetic study is conducted.

\section{Implications of biogeographic distribution for conservation}

Assessing the genetic diversity of plants (Mohammadi \& Prasanna, 2003), trees (Schaberg et al., 2008), animals (Reed \& Frankham, 2003) and microorganisms (Li \& Zhang, 2012) have been a budding trend for conservation genetics. This includes the bioresources such as food, pharmaceutical drugs, etc. (Wang et al., 2016; Li-Chan, 2015; Giavasis, 2014). With the ongoing threat of climate change, many biological organisms can have different responses, either a species change its genetic properties (genetic adaptation, Somero, 2010) or change its behavior, morphology and physiology (phenotypic plasticity, Charmantier et al., 2008) to adapt to the new climate and environment. However, if the species could not adapt to these new changes, the species population will decrease until extinction will occur (Thomas et al., 2004). Given these facts, this study contributes a new knowledge on many undermined but ecologically important biota such as the cosmopolitan tropical species Diderma hemisphaericum. It was revealed that the distribution of this species in Southeast Asia is widely 
Almadrones-Reyes et al.: Distribution of 18s rDNA variants of Diderma hemisphaericum collected in the Philippines and Vietnam

distributed in terms of morphology, but in terms of a deeper molecular scale, the environment plays an impact to create possible sympatric speciation across regional gene pool. At the end of the day, the diversity of the genes in a clear cut myxomycete species seems to be not directly influence by geographic isolation but most likely by environmental selection.

\section{Acknowledgements}

KJA-R, JLMB and JCR-S would like to thank the SusEnMan (Sustainable Environmental Management) Project (DAAD Project 57218030) headed by Prof. Dr. W. Steingrube for the grant given for their 3-months research internship. The authors would also like to acknowledge Prof. M. Schnittler and the International Office (University of Greifswald) for the financial support for the field collection and laboratory materials.

\section{Literature Cited}

Almadrones-Reyes, K. J., \& Dagamac, N. H. A. (2018). Predicting local habitat suitability in changing climate scenarios: Applying species distribution modelling for Diderma hemisphaericum. Current Research in Environmental \& Applied Mycology, 8(5): 492-500.

Aguilar, M., Fiore- Donno, A. M., Lado, C., \& Cavalier-Smith, T. (2014). Using environmental niche models to test the 'everything is everywhere' hypothesis for Badhamia. The ISME Journal, 8(4): 737-745.

Aylward, J., Dreyer, L. L., Steenkamp, E. T., Wingfield, M. J., \& Roets, F. (2015). Long- distance dispersal and recolonization of a fire- destroyed niche by a miteassociated fungus. Fungal biology, 119(4): 245- 256.

Bass, D., \& Boenigk, J. (2011). Everything is everywhere: a twenty- first century de-/reconstruction with respect to protists. Biogeography of microscopic organisms: Is everything small everywhere, 6: 88- 110.

Berdjeb, L., Parada, A., Needham, D. M., \& Fuhrman, J. A. (2018). Short- term dynamics and interactions of marine protist communities during the spring-summer transition. The ISME journal, 12: 1907- 1918.

Bernardo, J.L.M., Arioder, J.LQ., Almadrones-Reyes, K.J., \& Dagamac, N.H.A. (2018). Myxomycete communities occurring in fragmented forest patches in two municipalities of Laguna, Philippines. Community Ecology, 19(3): 289-299.

Boenigk, J., Wodniok, S., Bock, C., Beisser, D., Hempel, C., Grossmann, L., Lange, A., \& Jensen, M. (2018). Geographic distance and mountain ranges structure freshwater protist communities on a European scale. Metabarcoding and Metagenomics, 2: e21519.

Bonito, G. M., Gryganskyi, A. P., Trappe, J. M., \& Vilgalys, R. (2010). A global meta-analysis of Tuber ITS rDNA sequences: species diversity, host associations and longdistance dispersal. Molecular Ecology, 19(22): 4994- 5008.

Boyer, S. L., Markle, T. M., Baker, C. M., Luxbacher, A. M., \& Kozak, K. H. (2016). Historical refugia have shaped biogeographical patterns of species richness and phylogenetic diversity in mite harvestmen (Arachnida, Opiliones, Cyphophthalmi) endemic to the Australian Wet Tropics. Journal of Biogeography, 43(7): 1400- 1411.

Carrillo-Gavilán, A., Moreira, X., Zas, R., Gonzalez-Voyer, A., Vilà, M., \& Sampedro, L. (2015). Phylogenetic and biogeographical patterns in defensive strategies and quantitative allocation to chemical defences in Palaearctic and Nearctic pine trees. Journal of Biogeography, 42(4): 684- 693.

Charmantier, A., McCleery, R. H., Cole, L. R., Perrins, C., Kruuk, L. E., \& Sheldon, B. C. (2008). Adaptive phenotypic plasticity in response to climate change in a wild bird population. Science, 320(5877): 800-803.

Chen, S. L., Yan, S. Z., \& Li, Y. (2013). Species of the genus Diderma from China and their distributions. Mycosystema, 32: 200- 206.

Clement, M., Posada, D. C. K. A., \& Crandall, K. A. (2000). TCS: a computer program to estimate gene genealogies. Molecular ecology, 9(10):1657-1659.

Colwell, R. K. (2013). EstimateS: Statistical estimation of species richness and shared species from samples. Version 9. Available at: http://purl.oclc.org/estimates (accessed 23 April 2014).

Cotterill, F. P. D., Al- Rasheid, K., \& Foissner, W. (2007). Conservation of protists: is it needed at all? In Protist Diversity and Geographical Distribution, 8: 193- 209.

Craddock, E. M., Gall, J. G., \& Jonas, M. (2016). Hawaiian Drosophila genomes: size variation and evolutionary expansions. Genetica, 144(1): 107- 124.

Dagamac, N. H. A., Rojas, C., Novozhilov, Y. K., Moreno, G. H., Schlueter, R., \& Schnittler, M. (2017a). Speciation in progress? A phylogeographic study among populations of Hemitrichia serpula (Myxomycetes). PloS one, 12(4): $\mathrm{e} 0174825$.

Dagamac, N. H. A., Novizhilov, Y. K., Stephenson, S. L., Lado, C., Rojas, C., dela Cruz, T. E. E., Unterseher, M., Schnittler, M. (2017b). Biogeographical assessment of myxomycete assemblages from Neotropical and Asian Palaeotropical forest. Journal of Biogeography, 44: 1524 1536.

Dagamac N.H.A., dela Cruz T.E.E. (2015) Myxomycetes research in the Philippines: updates and opportunities. Mycosphere 6: 784-795.

Dagamac, N. H. A., Stephen E.G.,son, S. L., \& Dela Cruz, T. E. E. (2012). Occurrence, distribution and diversity of myxomycetes (plasmodial slime moulds) along two transects in Mt. Arayat National Park, Pampanga, Philippines. Mycology, 3(2): 119- 126.

Dalgleish D. (2015) Contexture. Excel tips, tutorials, and videos. Excel latitude and longitude calculations. Available from: http://www.contextures.com/excellatitudelongitude.html. Accessed 12 August 2018.

DeWalt, S. J., Schnitzer, S. A., Alves, L. F., Bongers, F., Burnham, R. J., Cai, Z., Carson, W.P., Chave, J., Chuyong, G.B., Costa, F.R.C., Ewango, C.E.N., Gallagher, R.V., Gerwing, J.J., Amezcua, E.G., Hart, T., Ibarra-Manriquez, G., Ickes, K., Kenfack, D., Letcher, S.G., Macia, M.J., Makana, J., Malizia, A., Martinez-Ramos, M., Mascaro, J., Muthumperumal, C., Muthuramkumar, S., Nogueira, A., Parren, M.P.E., Parthasarathy, N., Perez-Salicrup, D.R., 
Putz, F.E., Romero-Saltos, H.G., Reddy, M.S., Sainge, M.N., Thomas, D., van Melis, J., \& Ewango, C. E. (2015). Biogeographical patterns of liana abundance and diversity. Ecology of lianas, 11: 131- 146.

de Carvalho, A. L., Silva, H. R. D., de Araújo, A. F., AlvesSilva, R., \& Silva-Leite, R. R. D. (2007). Feeding ecology of Tropidurus torquatus (Wied)(Squamata, Tropiduridae) in two areas with different degrees of conservation in Marambaia Island, Rio de Janeiro, Southeastern Brazil. Revista Brasileira de Zoologia, 24(1): 222-227.

De Wit, R., \& Bouvier, T. (2006). 'Everything is everywhere, but, the environment selects'; what did Baas Becking and Beijerinck really say? Environmental microbiology, 8(4): $755-758$.

Dogma, I. J. (1975). Of Philippine mycology and lower fungi. Kalikasan Philippine Journal of Biology, 4: 69-105.

Excoffier, L. and H.E. L. Lischer (2010) Arlequin suite ver 3.5: A new series of programs to perform population genetics analyses under Linux and Windows. Molecular Ecology Resources, 10: 564- 567.

Feng, Y., \& Schnittler, M. (2017). Molecular or morphological species? Myxomycete diversity in a deciduous forest in northeastern Germany. Nova Hedwigia, 104(1-2): 359-380.

Finlay, B. J. (2002). Global dispersal of free-living microbial eukaryote species. Science, 296(5570): 1061-1063.

Finlay, B. J., \& Clarke, K. J. (1999). Ubiquitous dispersal of microbial species. Nature, 400(6747): 828.

Foissner, W. (1999). Protist diversity: estimates of the nearimponderable. Protist, 150(4): 363-368.

Foissner, W. (2006). Biogeography and dispersal of microorganisms: a review emphasizing protists. Acta protozoologica, 45(2): 111-136.

Foissner, W. (2008). Protist diversity and distribution: some basic considerations. Biodiversity and Conservation, 17: 235-242.

Giavasis, I. (2014). Bioactive fungal polysaccharides as potential functional ingredients in food and nutraceuticals. Current Opinion in Biotechnology, 26: 162173.

Gotanda, K. M., Sharpe, D. M., \& De Léon, L. F. (2015). Galapagos Mockingbird (Mimus parvulus) preys on an invasive mammal. The Wilson Journal of Ornithology, 127 (1): $138-141$.

Hood, G. M. (2010). PopTools version 3.2.5. Available from http://www.poptools.org. Accessed 18 August 2018.

Kamono, A., Matsumoto, J., Kojima, H., \& Fukui, M. (2009). Characterization of myxomycete communities in soil by reverse transcription polymerase chain reaction (RT-PCR)based method. Soil Biology and Biochemistry, 41(6): 13241330.

Ko Ko, T. W., Tran, H. T. M., Stephenson, S. L., Mitchell, D. W., Rojas, C., Hyde, K. D., ... \& Bahkali, A. H. (2010). Myxomycetes of Thailand. Sydowia, 62: 243-260.

Lado, C. (2005- 2018). An online nomenclatural information system of Eumycetozoa. Real Jardín Botánico, CSIC. Madrid, Spain. http://www.nomen.eumycetozoa.com. Accessed 14 July 2018.

Li, J., \& Zhang, K. Q. (2012). Genetic diversity of microorganisms. Yi chuan=Hereditas, 34(11): 1399-1408.

Li-Chan, E. C. (2015). Bioactive peptides and protein hydrolysates: research trends and challenges for application as nutraceuticals and functional food ingredients. Current Opinion in Food Science, 1: 28-37.

Librado, P., \& Rozas, J. (2009). DnaSP v5: a software for comprehensive analysis of DNA polymorphism data. Bioinformatics, 25(11): 1451- 1452.

Macabago S.A.B., Dagamac N.H.A., dela Cruz T.E.E., Stephenson S.L. (2017) Implications of the role of dispersal on the occur-rence of litter-inhabiting myxomycetes in different vegetation types after a disturbance: a case study in Bohol Islands, Philip-pines. Nova Hedwigia 104: 221236.

Macabago, S. A. B., dela Cruz, TEE, \& Stephenson, S. L. (2012). First records of myxomycetes from Lubang Island, Occidental Mindoro, Philippines. Sydowia, 64(1): 109-118.

Macabago, S. A. B. Dagamac, N.H.A., \& dela Cruz T. E. E (2010). Diversity and distribution of plasmodial myxomycetes (slime molds) from La Mesa Ecopark, Quezon City, Philippines. Biotropia, 17(2): 51-61.

McGill, B. J., Dornelas, M., Gotelli, N. J., \& Magurran, A. E. (2015). Fifteen forms of biodiversity trend in the Anthropocene. Trends in ecology \& evolution, 30(2): 104 113.

Mitchell, E. A., \& Meisterfeld, R. (2005). Taxonomic confusion blurs the debate on cosmopolitanism versus local endemism of free-living protists. Protist, 156(3): 263-267.

Mohammadi, S. A., \& Prasanna, B. M. (2003). Analysis of genetic diversity in crop plants - salient statistical tools and considerations. Crop science, 43(4): 1235-1248

Moncalvo, J. M., \& Buchanan, P. K. (2008). Molecular evidence for long distance dispersal across the Southern Hemisphere in the Ganoderma applanatum-australe species complex (Basidiomycota). Mycological research, 112(4): 425-436.

Mouly, A., \& Pisivin, C. (2007). Rare and threatened new endemic Ixora (Rubiaceae) from New Caledonia. Nordic Journal of Botany, 25(1-2): 14- 19.

Novozhilov, Y. K., Shchepin, O. N., Alexandrova, A. V., Popov, E. S., Dagamac, N. H. A. (2018). Altitudinal patterns of diversity of myxomycetes (Myxogastria) across tropical forests of Southern Vietnam. Protistology 12: 8196.

Novozhilov, Y. K., Schnittler, M., and Stephenson, S. (1999). Myxomycetes of the Taimyr Peninsula (north- central Siberia). Karstenia, 39: 77-97.

Perrigo, A. L., Romeralo, M., \& Baldauf, S. L. (2012). What's on your boots: an investigation into the role we play in protist dispersal. Journal of biogeography, 39(5): 9981003.

Pimm, S. L., Jenkins, C. N., Abell, R., Brooks, T. M., Gittleman, J. L., Joppa, L. N., ... \& Sexton, J. O. (2014). The biodiversity of species and their rates of extinction, distribution, and protection. Science, 344(6187): 1246752.

Reed, D. H., \& Frankham, R. (2003). Correlation between fitness and genetic diversity. Conservation biology, 17(1): 230-237.

Redeña-Santos, J.C., Duong, V.T., Schnittler, M., Dagamac, N.H.A. (2018). The first report of composition and occurrence of myxomycete assemblages in protected and unprotected plantation forests: A comparative study in Thai Nguyen City, Northern Vietnam. Plant Ecology and Evolution, 151: 231-240.

Redeña-Santos, J.C., Dunca, J. A. U., Thao, D. V., \& Dagamac, 
N. H. A. (2017) Myxomycetes occurring on selected agricultural leaf litters. Studies in fungi, 2:171-177.

Reynolds, D. R. (1981). Southeast Asian myxomycetes. Kalikasan: the Philippine journal of biology, 10:127-150.

Rojas, C., Schnittler, M., Biffi, D., \& Stephenson, S. L. (2008). Microhabitat and niche separation in species of Ceratiomyxa. Mycologia, 100(6): 843-850.

Rosing, W. C., Mitchell, D. W., Moreno, G., \& Stephenson, S. L. (2011). Additions to the myxomycetes of Singapore. Pacific Science, 65(3): 391-400.

Schaberg, P. G., DeHayes, D. H., Hawley, G. J., \& Nijensohn, S. E. (2008). Anthropogenic alterations of genetic diversity within tree populations: implications for forest ecosystem resilience. Forest Ecology and Management, 256(5): 855862.

Schnittler, M., Dagamac, N.H.A.,Novozhilov, Y.K. (2017a). Biogeographical patterns in myxomycetes. In Myxomycetes: Biology, Systematics, Biogeography, Ecology Eds: SL Stephenson \& C Rojas, Academic Press UK. pp. 299-331.

Schnittler, M., Shchepin, O.N., Dagamac, N.H.A., Dahl, M.B., Novozhilov, Y.K. (2017b). Barcoding myxomycetes with molecular markers: Challenges and Opportunities. Nova Hedwigia, 104: 323-341.

Schnittler, M., Stephenson, S. L., \& Novozhilov, Y. K. (2000). Ecology and world distribution of Barbeyella minutissima (Myxomycetes). Mycological Research, 104(12): 15181523.

Shchepin, O.N., Dagamac, N.H., Sanchez, O.M., Novozhilov, Y.K., Schnittler, M., \& Zemlyanskaya, I.V. (2017). DNA barcoding as a tool for identification of plasmodia and sclerotia of myxomycetes (Myxogastria) appearing in moist chamber cultures. Mycosphere , 8(10): 1904-1913.

Somero, G. N. (2010). The physiology of climate change: how potentials for acclimatization and genetic adaptation will determine 'winners' and 'losers'. Journal of Experimental Biology, 213(6): 912-920.

Sriramavaratharajan, V., Sudha, V., \& Murugan, R. (2016). Characterization of the leaf essential oils of an endemic species Cinnamomum perrottetii from Western Ghats, India. Natural product research, 30(9): 1085-1087.

Templeton, A. R., \& Sing, C. F. (1993). A cladistic analysis of phenotypic associations with haplotypes inferred from restriction endonuclease mapping. IV. Nested analyses with cladogram uncertainty and recombination. Genetics, 134 (2): 659-669.

Thomas, C. D., Cameron, A., Green, R. E., Bakkenes, M., Beaumont, L. J., Collingham, Y. C., Erasmus, B.F.N., de Siquera, M.F., Grainger, A., Hannah, L., Hughes, L., Huntley, B., van Jaarsveld, A.S., Midgley, G.F., Miles, L., Ortega-Huerta M.A., Townsend Peterson, A., Phillips, O.L \& Williams, S.E. (2004). Extinction risk from climate change. Nature, 427(6970): 145.

Tran, D. Q., Nguyen, H. T. N., Tran, H. T. M., \& Stephenson, S. L. (2014). Myxomycetes recorded from three lowland tropical forests in Vietnam. Mycosphere, 5: 662-672.

Tran, H. T., Stephenson, S. L., Hyde, K. D., \& Mongkolporn, O. (2008). Distribution and occurrence of myxomycetes on agricultural ground litter and forest floor litter in Thailand. Mycologia, 100(2): 181-190.
Uyenco, F. R. (1973). Myxomycetes of the Philippines. University of the Philippines Natural Science Research Center Technical Report, 12: 1-23.

van der Ent, A., Sumail, S., \& Clarke, C. (2015). Habitat differentiation of obligate ultramafic Nepenthes endemic to mount kinabalu and mount tambuyukon (Sabah, Malaysia). Plant ecology, 216(6): 789-807.

van der Gast, C. J. (2015). Microbial biogeography: the end of the ubiquitous dispersal hypothesis? Environmental Microbiology, 17(3): 544- 546.

Wang, J., Guleria, S., Koffas, M. A., \& Yan, Y. (2016). Microbial production of value-added nutraceuticals. Current opinion in biotechnology, 37: 97104

Wilkinson, D. M., Koumoutsaris, S., Mitchell, E. A., \& Bey, I. (2012). Modelling the effect of size on the aerial dispersal of microorganisms. Journal of Biogeography, 39(1): 89-97. 